\title{
Variability in Progenies of Poly Crosses and Station Cross of Sugarcane (Saccharum spp.)
}

\author{
G. Somu ${ }^{1 *}$ and T.E. Nagaraja ${ }^{2}$ \\ ${ }^{1}$ Department of Genetics and Plant Breeding, University of Agricultural sciences, \\ Bengaluru-65, Karnataka, India \\ ${ }^{2}$ (Plant breeding), AICRP on Sugarcane, Zonal Agricultural Research Station, V.C. Farm, \\ Mandya, India
}

*Corresponding author

\begin{abstract}
A B S T R A C T
Keywords

Poly Crosses,

Station Cross,

Sugarcane

(Saccharum spp.)

Article Info

Accepted:

06 July 2018

Available Online:

10 August 2018

Genetic variability and heritability are useful parameters that can help the breeding during different stages of crop improvement. The success of such programme will largely depend on the extents of genetic variability available in the base population and heritability of the characters under improvement. Therefore, a clear understanding of genetic parameters is of paramount importance to develop a breeding strategy.Proper exploitation of variability in a crop like sugarcane with a complex ploidy and a high level of heterozygosity is a complicated process. The study was undertaken to determine the potential of poly crosses and station cross in sugarcane, obtained by pollinating the female parents Co 94012, Co8371, 86V46 and Co $7201 \times$ Co 99006 to generate variants for eight traits and frequency distribution pattern of variants, hence generated. 642 seedlings raised from three poly crosses and one station cross, comprising high sugared commercial varieties were investigated.Left skewed distribution (Skewness $<0$ ) was observed in all crosses, thereby indicating that most values are concentrated on the right of the mean. Leptokurtic distributions in progeny of PCII and PC III derived from Co 8371 and 86V46 PC, inferred that distribution of progeny presented higher peaks around the mean compared to normal distributions, which leads to thick tails on both sides. This signified that the most of the seedlings from Co 8371 and Co 94012 performed superior to the population mean.
\end{abstract}

\section{Introduction}

Most of the sugarcane varieties in the world are breeds of $S$. spontaneum $\times S$. officinarum. To reduce the negative effects of $S$. spontaneum and to retain the high sucrose producing ability of $S$. officinarum during crosses, a series of backcrosses were made between the inter-specific hybrids and $S$. officinarum parents. This led to the "noblization" of Saccharum spp. hybrids (Sreevastava et al., 1999). This was a major breakthrough in sugarcane varietal improvement programs in terms of improved 
sugar productivity, high disease resistance and high ratooning ability. Although noblization was highly successful but due to limits of the gene pool exploited during traditional breeding programs, very limited progress has been achieved in increasing sugar content.

Understanding of various genetic parameters that govern a population under improvement is essential for proper planning and direction of plant breeding programme. Genetic variability and heritability are useful parameters that can help the breeding during different stages of crop improvement. The success of such programme will largely depend on the extents of genetic variability available in the base population and heritability of the characters under improvement. Therefore, a clear understanding of genetic parameters is of paramount importance to develop a breeding strategy. Proper exploitation of variability in a crop like sugarcane with a complex ploidy and a high level of heterozygosity is a complicated process (Babu et al., 2009). The main difficulty in improvement of sugarcane is selection at seedling stage. Further, it is a vital stage of selection because it provides the base population for remaining and more effective stages of selection (Ram bakshi et al., 2009). New sugarcane cultivars are developed through the selection of vegetatively propagated genotypes, obtained from true seed after hybridization of superior parents. Selection at early stages in sugarcane breeding programmes is generally based on refractometer Brix and tiller number and millable cane are the important characteristics. Many breeders indicated that heritability of juice quality in sugarcane, including Brix (Shanthi et al., 2005), is moderate to high and therefore can be improved with the correct selection pressure. Brix was highly correlated with sucrose and selection for high sucrose could begin as early stage and most of the genetic variation for Brix could be attributed to additive effects (Ram bakshi et al., 1997).
The study was undertaken to determine the potential of poly crosses and station cross in sugarcane, obtained by open pollinating the female parents Co 94012, Co8371, 86V46 and Co $7201 \times$ Co 99006to generate variants for eight traits and frequency distribution pattern of variants, hence generated. 642 seedlings raised from three poly crosses and one station cross, comprising high sugared commercial varieties were investigated. The different traits of test seedlings evaluated in seedling nursery, inferred the generation of highly variable population with significant differences in test genotypes.

\section{Materials and Methods}

The material for the study comprised of seedlings developed from the fluffs of different cross combinations effected at National Hybridization Garden, Sugarcane Breeding Institute, Coimbatore under AICRP (Sugarcane) and three standard checks viz. CoVC 99463, Co 86032 and Co 62175 were used in this study for vigour and quality parameters during eksali 2014. The details of the different crosses and checks used in the present investigation are presented in Table 1. All seedlings of crosses were evaluated as per the specifications of AICRP (Sugar cane) at ZARS, V.C. Farm, Mandya. Six meters of row length with four feet of row to row spacing was maintained, seedling to seedling spacing one foot was used for evaluation during eksali 2014. All the recommended package of practices was adopted to raise the better crop stand. The main objective of the study was to estimate the genetic variability for number of tillers, number of millable canes, number of internodes, intermodal length and HR Brix per cent (top, middle and bottom).

\section{Results and Discussion}

642 seedlings derived from different crosses were evaluated for different traits was used for 
all statistical analysis. The individual seedlings were evaluated on unreplicated plots, descriptive statistics were worked out for each cross, the class intervals were constituted for all traits under study.

The frequency distribution of progeny for millable cane and Brix content for each general cross combination was determined and represented graphically. The analysis of variance was performed individually for each character and total variation was partitioned into different sources of variation. The results are presented in Table 2.

Analysis of variance revealed significant differences due to genotypes for all eight characters viz., number of tillers/plant, number of millable canes/plant, number of internodes, cane diameter, internode length, Brix per cent (top), Brix per cent (middle) and Brix per cent (bottom) in all cross combinations.

The heterogeneity was observed within cross. Highly significant differences in the test genotypes for all traits indicated the generation of highly variable population from poly cross and station cross in sugarcane.

The general statistics for each type of general cross and station cross viz., Co 94012(PCI), Co 8371(PC II), 86V46 (PC III) and Co 7201 $\times$ Co 99006 (SC) were described in Table 3 5 .

Table.1 Pedigree of the genotypes of different cross combinations and checks in seedling nursery of sugarcane

\begin{tabular}{|c|c|c|}
\hline \multicolumn{1}{|c|}{ SI. No. } & Genotypes & Pedigree \\
\hline Poly Crosses (PC) & & Co 94012 PC \\
\hline 1 & PC 14-43 (PC I) & Co 8371 PC \\
\hline 2 & PC 14-52 (PC II) & 86 V46 PC \\
\hline Station Cross (SC) & PC 14-49 (PC III) & Co $7201 \times$ Co 99006 \\
\hline 1 & SC $14-37$ (SC) & Co 6806 PC \\
\hline Standard Checks & CoVC 99463 & Co $62198 \times$ CoC 671 \\
\hline 1 & Co 86032 & Co $951 \times$ Co 419 \\
\hline
\end{tabular}

Where, $\mathrm{PC}=$ Poly Crosses, $\mathrm{SC}=$ Station Crosses

Table.2 Analysis of variance for eight characters in progenies of Poly cross and station cross

\begin{tabular}{|c|c|c|c|c|c|c|}
\hline \multirow{4}{*}{$\begin{array}{l}\text { SI. } \\
\text { No. }\end{array}$} & \multirow[t]{4}{*}{ Traits } & \multicolumn{5}{|c|}{ SOURCE OF VARAITION } \\
\hline & & \multicolumn{4}{|c|}{ Genotypes (MSS) } & \multirow{3}{*}{$\begin{array}{l}\text { Error } \\
\text { (MSS) }\end{array}$} \\
\hline & & PC I & PC II & PC III & SC & \\
\hline & & $\mathrm{N}=323$ & $\mathrm{~N}=194$ & $\mathrm{~N}=13$ & $\mathrm{~N}=112$ & \\
\hline 1. & Tillers/plant & $13.27 * *$ & $6.68 * *$ & $10.08 * *$ & $6.62 * *$ & 1.23 \\
\hline 2. & Millable canes /plant & $10.04 * *$ & $5.29 * *$ & $7.64 * *$ & $5.34 * *$ & 0.50 \\
\hline 3. & Number of internodes & $11.55^{* *}$ & $4.94 * *$ & $2.74 * *$ & $3.36^{* *}$ & 3.30 \\
\hline 4. & Cane diameter $(\mathrm{cm})$ & $0.12 *$ & $0.05^{*}$ & $0.26^{*}$ & $0.05^{*}$ & 0.03 \\
\hline 5. & Internode length $(\mathrm{cm})$ & $9.44 * *$ & $5.21 * *$ & $2.12 * *$ & $3.29 * *$ & 1.17 \\
\hline 6. & Brix per cent (Top) & $3.48 * *$ & $3.74 * *$ & $2.48 * *$ & $4.12 * *$ & 0.40 \\
\hline 7. & Brix per cent (Middle) & $3.57 * *$ & $3.60 * *$ & $2.52 * *$ & $4.07 * *$ & 0.26 \\
\hline 8. & Brix per cent (Bottom) & $3.43 * *$ & $3.50 * *$ & $2.23 * *$ & $4.00 * *$ & 0.16 \\
\hline
\end{tabular}


Table.3 Descriptive statistics for number of millable canes/plant in progeny of different cross combinations

\begin{tabular}{|c|c|c|c|c|c|c|c|c|c|}
\hline $\begin{array}{l}\text { Sl. } \\
\text { No. }\end{array}$ & $\begin{array}{c}\text { Cross } \\
\text { Combination }\end{array}$ & $\begin{array}{c}\text { No. of } \\
\text { seedlings evaluated }\end{array}$ & Mean & SE & Minimum & Maximum & Variance & Skewness & Kurtosis \\
\hline 1. & $\begin{array}{l}\text { PC } 14-43(\mathrm{PC} \mathrm{I}) \\
\text { Co } 94012 \text { PC }\end{array}$ & 323 & 9.34 & 0.21 & 2.00 & 20.00 & 10.04 & 0.005 & 0.16 \\
\hline 2. & $\begin{array}{l}\text { PC 14-49 (PC III) } \\
86 \mathrm{~V} 46 \text { PC }\end{array}$ & 13 & 8.15 & 1.09 & 3.00 & 12.00 & 7.64 & -0.61 & -0.46 \\
\hline 3. & $\begin{array}{l}\text { PC } 14-52 \text { (PC II) } \\
\text { Co } 8371 \text { PC }\end{array}$ & 194 & 10.05 & 0.19 & 4.00 & 18.00 & 6.68 & -0.22 & 0.26 \\
\hline 4. & $\begin{array}{l}\text { SC } 14-37(\mathrm{SC}) \\
\text { Co } 7201 \times \text { Co } 99006\end{array}$ & 112 & 9.76 & 0.26 & 2.00 & 14.00 & 5.34 & -0.79 & 0.99 \\
\hline & Total & 642 & & & & & & & \\
\hline
\end{tabular}

$\mathrm{PC}=$ Poly Crosses, $\mathrm{SC}=$ Station Crosses

Table.4 Descriptive statistics for cane diameter $(\mathrm{cm})$ in progeny of different cross combinations

\begin{tabular}{|r|l|c|c|c|c|c|c|c|c|}
\hline $\begin{array}{c}\text { Sl. } \\
\text { No. }\end{array}$ & Cross Combination & $\begin{array}{c}\text { No. of seedlings } \\
\text { evaluated }\end{array}$ & Mean & SE & Minimum & Maximum & Variance & Skewness \\
\hline 1. & $\begin{array}{l}\text { PC 14-43 (PC I) } \\
\text { Co 94012 PC }\end{array}$ & 323 & 2.06 & 0.19 & 1.20 & 3.60 & 0.12 \\
\hline 2. & $\begin{array}{l}\text { PC 14-49 (PC III) } \\
\text { 86V46 PC }\end{array}$ & 13 & 2.45 & 1.00 & 1.80 & 3.50 & 0.26 & 0.65 \\
\hline 3. & $\begin{array}{l}\text { PC 14-52 (PC II) } \\
\text { Co 8371 PC }\end{array}$ & 194 & 1.83 & 0.17 & 1.20 & 2.40 & 0.05 & -0.15 \\
\hline 4. & $\begin{array}{l}\text { SC 14-37 (SC) } \\
\text { Co 7201 } \times \text { Co 99006 }\end{array}$ & 112 & 1.86 & 0.20 & 1.20 & 2.40 & 0.05 & -0.03 \\
\hline
\end{tabular}

$\mathrm{PC}=$ Poly Crosses, $\mathrm{SC}=$ Station Crosses 
Table.5 Descriptive Statistics for brix per cent (bottom) in progeny of different cross combinations

\begin{tabular}{|c|c|c|c|c|c|c|c|c|c|}
\hline $\begin{array}{l}\text { Sl. } \\
\text { No. }\end{array}$ & Cross Combination & $\begin{array}{l}\text { No. of seedlings } \\
\text { evaluated }\end{array}$ & Mean & SE & Minimum & Maximum & Variance & Skewness & Kurtosis \\
\hline 1. & $\begin{array}{l}\text { PC } 14-43(\text { PC I) } \\
\text { Co } 94012 \text { PC }\end{array}$ & 323 & 18.63 & 0.12 & 13.00 & 23.00 & 3.433 & -0.653 & 0.239 \\
\hline 2. & $\begin{array}{l}\text { PC 14-49 (PC III) } \\
86 V 46 \text { PC }\end{array}$ & 13 & 18.54 & 1.30 & 15.00 & 20.50 & 2.228 & -1.043 & 1.342 \\
\hline 3. & $\begin{array}{l}\text { PC 14-52 (PC II) } \\
\text { Co } 8371 \text { PC }\end{array}$ & 194 & 18.35 & 0.16 & 13.50 & 23.00 & 3.498 & -0.588 & -0.126 \\
\hline 4. & $\begin{array}{l}\text { SC } 14-37(\mathrm{SC}) \\
\text { Co } 7201 \times \text { Co } 99006\end{array}$ & 112 & 18.06 & 0.24 & 13.00 & 21.00 & 3.997 & -0.530 & -0.487 \\
\hline & Total & 642 & & & & & & & \\
\hline
\end{tabular}

Table.6 Performance of progeny in different general cross combinations

\begin{tabular}{|c|c|c|c|c|}
\hline $\begin{array}{l}\text { Sl. } \\
\text { No. }\end{array}$ & Crosses & $\begin{array}{c}\% \text { poor } \\
\text { seedlings } \\
\text { /population } \\
(<16.0 \text { HIR Brix })\end{array}$ & $\begin{array}{c}\% \text { Average } \\
\text { seedlings } \\
\text { /population } \\
\text { (16.1 -20.0 HR Brix) }\end{array}$ & $\begin{array}{l}\% \text { Elite seedlings } \\
\text { / population } \\
\text { (>20.1 HR Brix })\end{array}$ \\
\hline 1. & $\begin{array}{l}\text { PC 14-43 } \\
\text { Co } 94012 \text { PC }\end{array}$ & 10.80 & 69.10 & 20.10 \\
\hline 2. & $\begin{array}{l}\text { PC 14-52 } \\
\text { Co8371 PC }\end{array}$ & 14.40 & 69.60 & 16.00 \\
\hline 3. & $\begin{array}{l}\text { PC 14-49 } \\
86 V 46 \text { PC }\end{array}$ & 7.70 & 84.60 & 7.70 \\
\hline 4. & $\begin{array}{l}\text { SC 14-37 } \\
\text { Co } 7201 \times C o 99006 \text { SC }\end{array}$ & 19.60 & 68.80 & 11.60 \\
\hline
\end{tabular}

$\mathrm{PC}=$ Poly Crosses, $\mathrm{SC}=$ Station Crosses 
Fig.1 Frequency Distribution of Progeny of Poly Cross of Co 94012(PC I) for number of millable canes / plant and Brix per cent
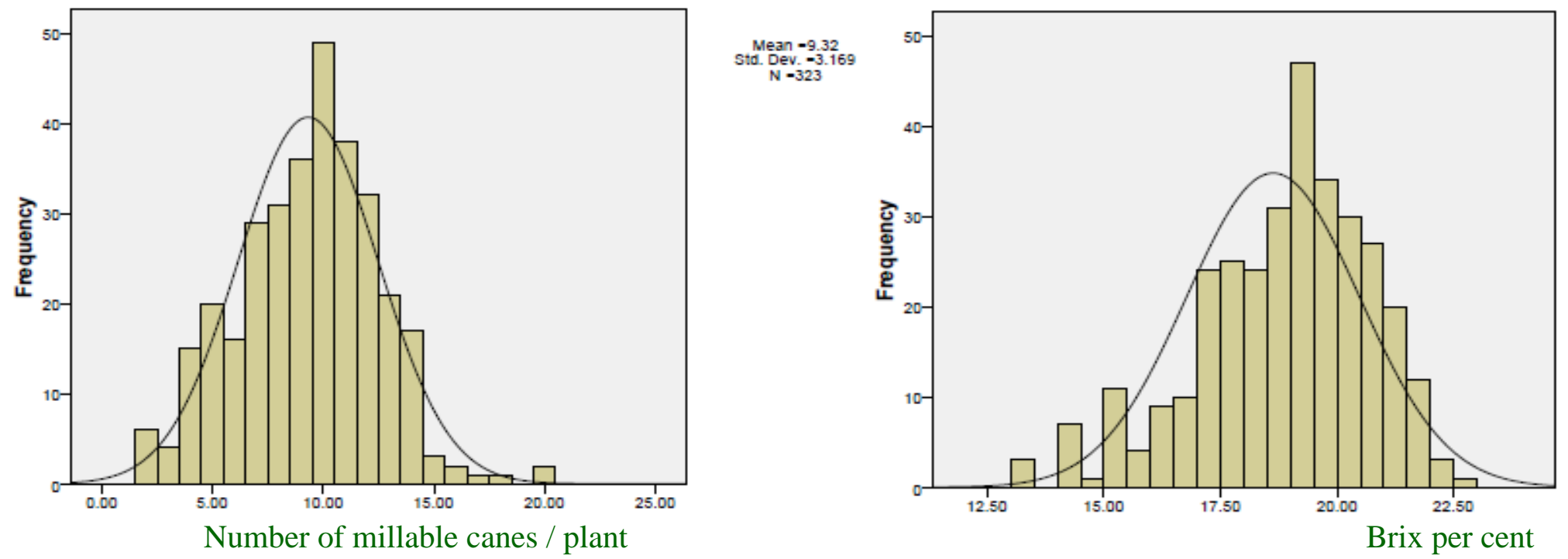

Mean -18.63
Sto. Dev. -1.853
$N=323$

Fig.2 Frequency Distribution of Progeny of Poly Cross of 86V46 (PC III) for number of millable canes / plant and Brix per cent
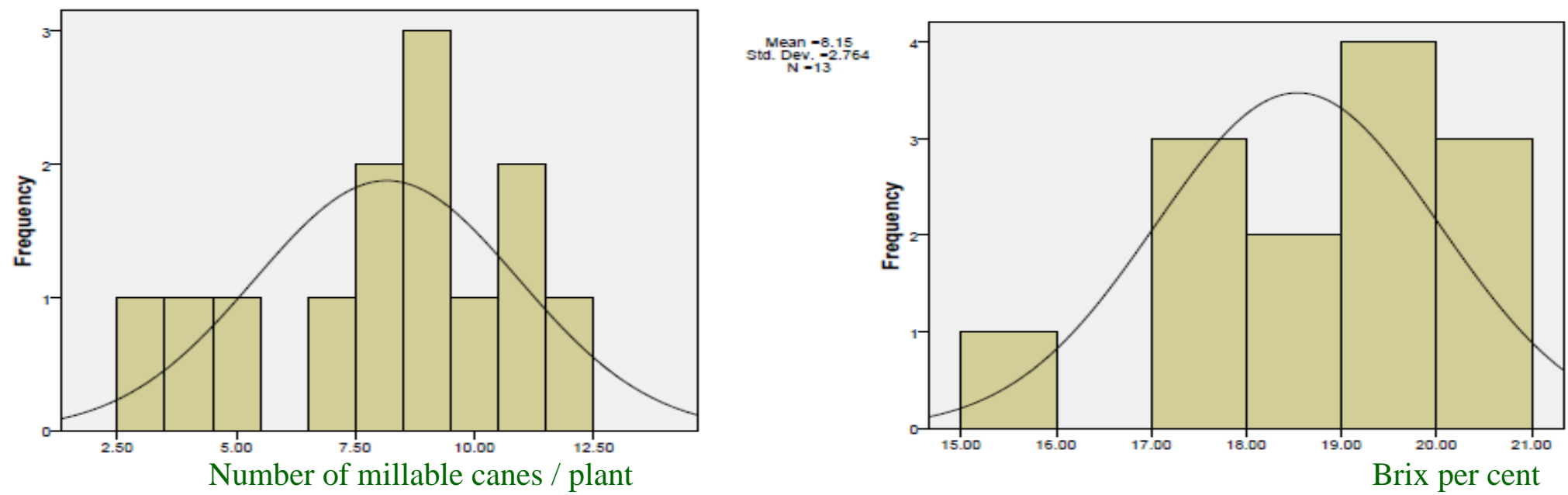

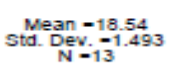


Fig.3 Frequency distribution of progeny of poly cross of Co 8371(PC II) for number of millable canes / plant and Brix per cent
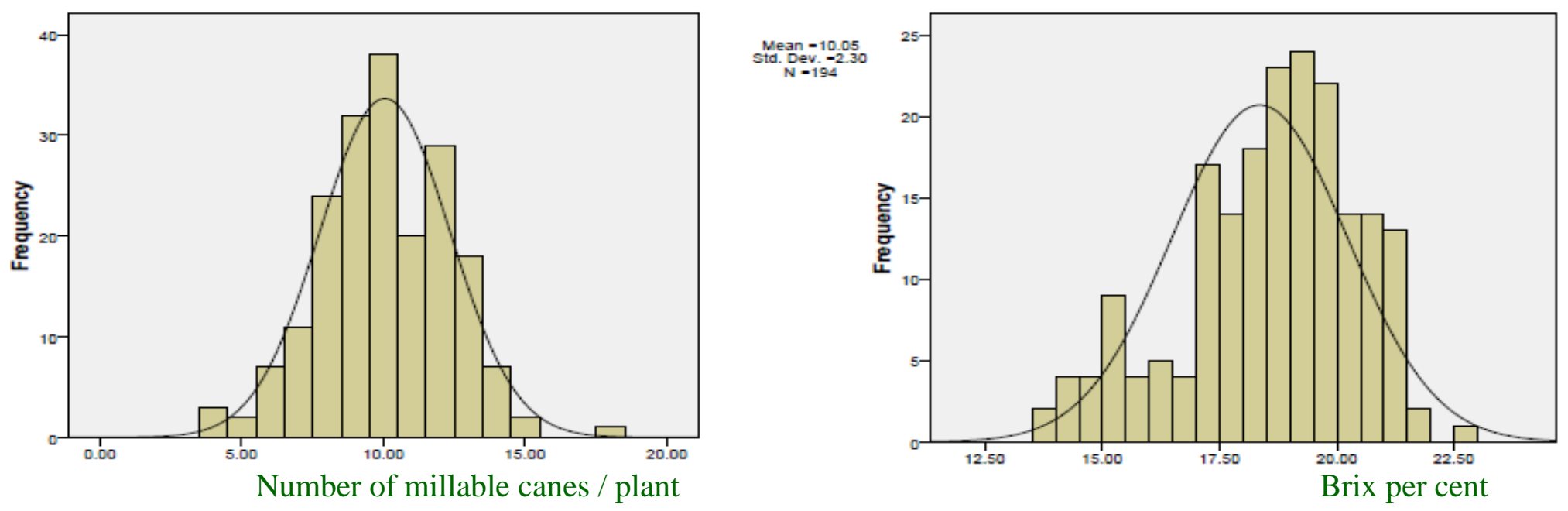

Mean -18.35
Sta. Dev -1.87
$N-194$

Fig.4 Frequency distribution of progeny of station cross of Co 7201 x Co 99006 (SC) for number of millable canes / plant and Brix per cent
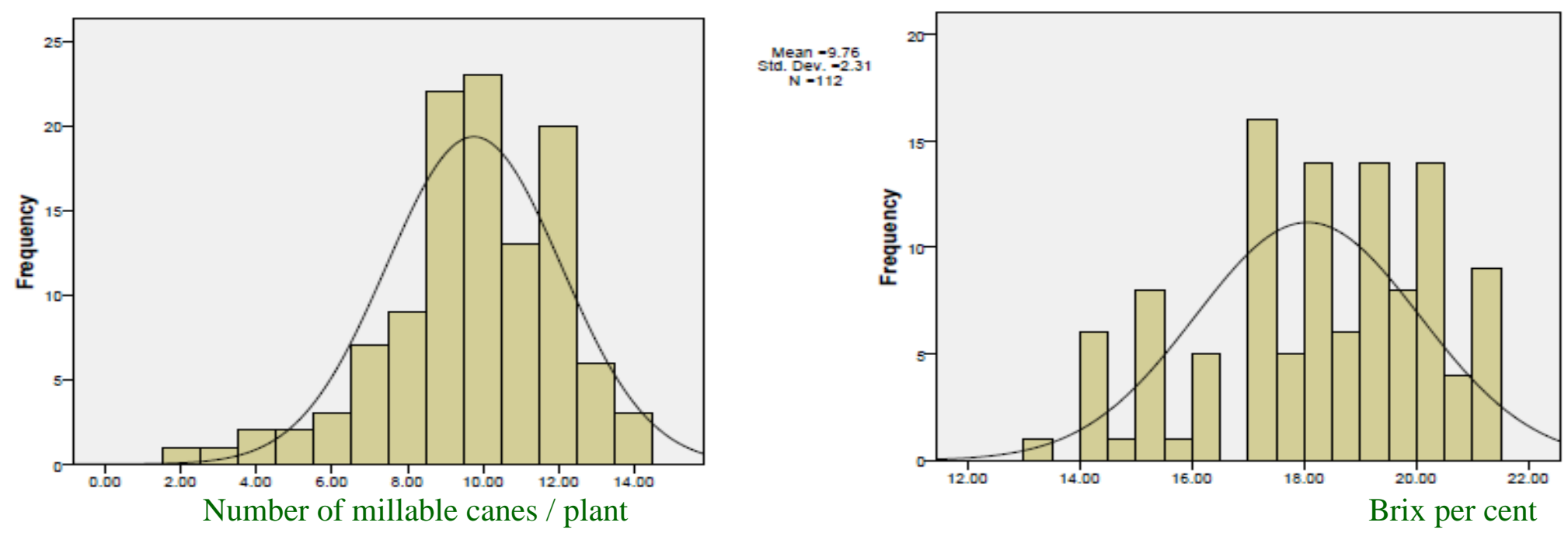
The highest mean value for millable canes per plant was recorded in PC II (10.05) followed by SC (9.76) with range of 4.00 to 18.00 and 2.00 to 14.00 . High variance (15.92) was observed in PC I (10.04) and lowest was observed in SC (5.34). Skewness in PC II, PC III and SC were observed $<0$ and remaining cross was observed positive skewness. Negative curtosis in PC III and remaining crosses shows positive kurtosis (Table 3 ).

Total of 642 progenies from poly cross and station cross combinations were studied (Table 4). The highest mean value for cane diameter was recorded in PC III (2.45) and lowest in PC II (1.83) with range of 1.80 to 3.50 , and 1.20 to 2.40 . High variance was observed in PC III (0.26) and lowest was observed in SC and PC II (0.05). Skewness in PC II and SC were negative and remaining crosses were observed positive skewness. All cross combinations shows positive kurtosis for cane diameter except PC III.

Progenies from different cross combinations studied (Table 5), the highest mean value for bottom Brix per cent was recorded in PC I $(18.63 \%)$ followed by SC III (18.06 \%) with range of 13.00 to 23.00 , and 13.00 to 21.00 . High variance (3.99) was observed in SC and lowest was observed in PC II (2.22). The crosses viz., PC II, SC shows negative kurtosis and remaining crosses shows positive kurtosis for bottom Brix per cent.

Left skewed distribution (Skewness $<0$ ) was observed in all crosses, thereby indicating that most values are concentrated on the right of the mean. Graphically, the frequency distribution in the progeny of each cross was presented in Figure 1-4. Leptokurtic distributions in progeny of PCII and PC III derived from Co 8371 and 86V46 PC, inferred that distribution of progeny presented higher peaks around the mean compared to normal distributions, which leads to thick tails on both sides. This signified that the most of the seedlings from Co 8371 and Co 94012 performed superior to the population mean and in the direction of higher scale and hence, surfaced as potential female parents to generate high frequency of elite seedlings for Brix content.

Based on Brix value, the categorization of seedlings in three classes viz., poor $(<16.0$ Brix content), average (16.1-20.0 Brix content) and elite (> 20.1.0 Brix content), was done (Table 6). Co 94012 PC generated the highest per cent of elite (20.0) seedlings followed by Co8371 PC (16.00) and Co7201xCo99006 SC(11.60) having Brix content $>20$ per cent (Surinder et al., (2012).

\section{References}

Babu, C., Koodalingam, K., Natarajan, U.S., Shanthi, R.M. and Govindaraj, P., 2009. Genetic enhancement of sugarcane (Saccharum spp. hybrids) for resistance to red rot disease and economic traits.Indian J. Agril.Sci., 4: 97-107.

Bhagyalakhsmi, K.V. and Somarajan, K.G., 1999, Modified augmented design for early selection stages in sugarcane and its limitation. Sugar Tech., 1: 63-66.

D' hont, A., Rao, P.S., Feldmann, P., Grivet, L., Islam-N. Faridi, Taylor and Pand glaszmann, J.C., 1995, Identification and characterization of sugarcane intergeneric hybrids, Saccharumofficina rum $\mathrm{x}$ Erianthusarundinaceus, with molecular markers and DNA in situ hybridization. Theor. Appl. Genet., 91: 320-326.

Ram bakshi, 2009, Effects of season of ratooning and field position of seedling ratoon clumps on selection in sugarcane (Saccharum officinarum) Indian J. Agril.Sci., 79(10): 790-3.

Ram bakshi, Chaudhary, B.S., and Singh, S., 1997, Response to indirect selection in 
ratoon of sugarcane seedlings. Aus $J$. Agril.Res., 48: 207-13.

Shanthi, R.M., Alarmelu, S., and Balakrishan, R., 2005, Role of Female Parent in the inheritance of Brix in early selection stages of sugarcane. Sugar Tech., 7(2\&3): 39-43.

Sreevastava, H. M., Sangeeta Srivastava, Rajesh kumar and Misra, G. P., 1999,
Genetic Divergence among Interspecific Hybrids of Sugarcane. Sugar Technol., 1(12): 19 - 22.

Surinder K. Sandhu, K.S. Thind and Pritpal Singh., 2012, Variability Trends for Brix Content in General Cross Combinations of Sugarcane (Saccharum spp. Complex). World Journal of Agricultural Sciences 8(1): 113-117.

\section{How to cite this article:}

Somu, G. and Nagaraja, T.E. 2018. Variability in Progenies of Poly Crosses and Station Cross of Sugarcane (Saccharum spp.). Int.J.Curr.Microbiol.App.Sci. 7(08): 629-637.

doi: https://doi.org/10.20546/ijcmas.2018.708.068 